\title{
Agribusiness System Hub for Rural Agricultural Cooperative Societies in Developing Countries
}

\author{
Kenedy Aliila Greyson \\ Dar es Salaam Institute of Technology, Dar es Salaam, Tanzania
}

Copyright $\mathrm{C} 2018$ by authors, all rights reserved. Authors agree that this article remains permanently open access under the terms of the Creative Commons Attribution License 4.0 International License

\begin{abstract}
This paper proposes the alternative method to be used in sharing agribusiness resources to the rural areas inhabitants of developing countries. The small scale enterprises in the rural areas of developing countries are in agribusiness category. Enterprises in those areas are categorized by the different products produced in a small scale throughout the year. Moreover, the market places are limited. It is recommended that, when agribusiness system hub are utilized effectively in cooperative unions of developing countries, it will strengthen the capacity to access markets, create jobs, enhance income, and hence reduce poverty in their communities. The papers consider the whole community as one Business Company and manage the business collectively using agribusiness system hub. Data are collected from the various selected communities are discussed and the model to address the problem is presented.
\end{abstract}

Keywords Agribusiness Systems Hub, Cooperative Union, Developing Countries, Enterprises, Rural Areas

\section{Introduction}

\subsection{Rural area in Developing Countries}

Large numbers of people in developing countries live in the rural areas and depend on agro-economy activities. Citizens in the rural areas of developing countries live below poverty line. We can characterize the rural areas in developing countries as areas with shortages of goods and services, shortage of employment opportunities, lack of entrepreneurship opportunities, lack of development infrastructure, and many more.

\subsection{Agriculture in the Rural Area}

Agricultural activities in the rural areas are in small scales. Related farming activities, as an example, include the acquisition and preparation of the farm, plantation, purchasing of inputs, crops growing, harvesting, processing, storage, marketing and sales.

Seeds and fertilizers are inputs purchased from the various suppliers. Overall cost and quality of item to be purchased are among the major factors used in this process. Production processes include functions such as fertilizing, watering crops, applying pesticides, and deploying manpower. After harvesting products, the next stage is the crop processing. Crop processing is an essential stage of converting raw harvested agricultural products into marketable products ready for storage. The storage capacity defines the quantity to be in stock. Agribusiness marketing involve buying and selling of agricultural products. Therefore, integration of information technology (IT) systems in the local communities of developing countries can assist in raising agricultural products and respective markets in various areas.

Agriculture is the most substantial economic sector in the rural areas of sub-Saharan developing countries. For instance, more than 70 percent of Tanzanians live in the rural areas and more than 62 percent consider agriculture as their main economic activity. Rural areas in developing countries are characterized by the poor or lack of socioeconomic tools and facilities such as market places, education and information centers, etc. The mini scale business with a change of products (or multi products) and seasonal products are among the challenging issues. Most households produce various products a year. The concept of the multi products is due to the change of weather and available opportunity during the respective season. For example, within 12 months of a year, a household would change various products and activities such as crops production, fishing, livestock production, or combination of these, as their cash income activities. In many areas, there are one day for the general market and livestock auction-day once in every two weeks. Therefore, the implementation of tools to enhance agricultural activities in the rural inhabitants is inevitable. However, agricultural sector in developing countries is among the challenging sector due to many factors such as climate change, poverty, illiteracy, change of price and market, etc. Hence, the main 
concern of this paper is to increase productivity and diversity of food.

In order to support the delivery and value chain of any agriculture or agriculture allied product, cooperative societies were formed. Its main function is to provide support and sustainability to rural economic activities $[1,16]$. Therefore, the cooperative union function is to promote the social economic activities.

The Information and Communications Technologies (ICTs), on the other hand, is among the tools to support cooperative unions in the disadvantaged areas such as rural areas of developing countries. When utilized effectively in cooperative unions of developing countries, ICT will strengthen the capacity to access markets, create jobs, enhance income, and hence reduce poverty in their communities. The customization of general enterprise resource planning (ERP), as it is for much other business software, is complicated and expensive for dynamic small scale businesses. In principle, to manage and to plan combined business processes in agribusiness enterprise, such as purchasing, human resources (HR), production, processing, marketing \& sales, an agribusiness hub system tool is needed. A well planned and designed enterprise resource planning for agribusiness is used to optimize resources, improve operational efficiency and profits. It comes to the conclusion that, in order to bring success in agribusiness, its core processes such as, purchasing, production, processing, stock \& inventory, marketing, and sales must be well studied and managed.

The agribusiness system hub model is developed to address challenges related to agribusiness in the rural areas of developing countries. We adopt the definition of ERP as an integrated suite of modules that forms the transactional system of record of a business. The hub allows many farmers, producing various crops and related activities, fishing, livestock and bee keeping, to be accommodated collectively in a single system.

Integrated information technology solutions, agribusiness system hub, is modeled to integrate various agribusiness business functions in the entire community. Factors linked with the success of agribusiness systems in the agricultural enterprise were identifies. Conceptual database design and the agribusiness system functionalities leading to the customization to accommodate the community agricultural commodities in the rural areas of developing countries are presented. Among the challenges facing ERP in agriculture sector is reported as constraints of ERP technologies and the lack of understanding agricultural functional processes in agricultural enterprise [1]. Unlike developed countries, lack of big farms, computer illiteracy, poor network infrastructure in the rural areas, are among the problems in the developing countries. Moreover, the anticipated risks are the lack of technical support in the rural areas where most peasants live.

It is reported in $[2,6]$ that, in the rural areas of developing countries, the main cause of ERP failures is the lack of knowledge for some practitioners about what to measure or assess in the context of ERP systems. If well managed, ERP will assist in all stages from planning to the sales. In many literatures, agriculture is defined as the art and science of producing crops and the livestock for economic purposes [2].

There are several efforts made towards the implementation of IT systems in business enterprises. Factors associated with the success and failure of ERP systems are identified in $[3,4,5,6]$. Authors develop a model to analyze the relationships between key factors and the success of such systems. Authors in [7] also provide a comprehensive ERP systems success measurement model. Other factors include, supporting decision making, scalable, easily deployed and accessed. An author in [8] describes some common challenges which cause the major constraints for ERP system adoption. Authors in [9] present smart farming concepts. They provide reference architecture for Farm Software Ecosystems to map, assess design and implement Farm Software Ecosystems. ERP development stages are explained in $[10,11,13]$. Authors in [14] give the factors that influence the effect of ERP adoption to help improve the business environment of the ERP users, especially in agricultural industry. Author in [15] addresses challenges in the developing world, such as global food security, poverty reduction, and sustainable natural resource management. The ERP system will gather data related to the agricultural enterprise operations, analyze and allow all key operators and stakeholders to see the progress of the business and to make better decisions. The decisions will lead towards better planning strategies, organizing resources such as manpower and money, and taking corrective action, if any.

The paper is structured as follows: introduction of the research is presented in section 1 , followed by the problem statement in section 2. ERP theory in section 3 Section 4 presents the concept of agribusiness system hub. Methodology and conclusion are presented in section 5 and 6 , respectively.

\section{Problem Statement}

The lack of business opportunities, unemployment, and household poverty, are among the major problems in the rural communities of most developing countries. Along with that, the markets for the products are also limited. The focus of the governments through cooperative unions in those countries is to balance and to increase revenues in the disadvantaged areas such as rural areas of developing or poor countries. Small scale businesses in the rural area communities of most developing countries are characterized by different inputs sources for the survivals throughout the year. Most business software are not designed specifically for these kind of enterprises but for the well-defined organizations and companies. In that case, 
cooperative unions need modern technologies and methods to increase production of agricultural products and the processing and marketing of such products. Integrating ICT tools into agro-economy activities and functional stages, will increase the efficiency in the agribusiness activities and related operational flow.

\section{ERP Theory}

\subsection{Background}

The Internet gives opportunities for enterprises to reach new markets, modernize and streamline their internal business processes. In principle, ERP is referred to as the category of business-management software, typically a suite of integrated applications that an enterprise or organization use to collect, store, manage and interpret data from business activities. In agribusiness sector, ERP can be used to manage inputs, manpower, production, inventory, marketing, and finance. Regardless of the type, nature, and size of the business and related functional units, the need for the accurate record keeping, resource allocations, planning, analysis, and reporting are necessary [4]. Hence, Information Technology (IT) systems for agribusiness sector, significantly increases the ability to feed the fast growing population in the developing countries in a sustainable way. That can only be accomplished if the system will increase the farming efficiency, create engagement with right partners, create market awareness, and manage the price.

\subsection{ERP in Agribusiness}

The business processes in agricultural enterprise differ from each other based on the product/crops produced. For example, cassava cultivation processes differ from millet or sugar cane cultivation. Information about the types of crops and seeds, fertilizers, weather and seasons, soil type, fertilizer, pesticide, and price trends, are among the information to be collected during the planning and implementation of the IT system. In order to increase efficiency and profit in agribusiness, ERP will gather, collect, retrieve and analyze data from numerous functional activities and processes. This is achieved by ERP system shown in Figure 1. Business processes in agribusiness enterprise include back-office operations, such as finance, production, processing, and stock \& inventory processes. The front-office operations which include marketing, sales, distribution, delivery, and customer service processes. Business processes share data from the database to support managers and/or stakeholders to make decisions.

Finance functional process in agriculture supports farmers to manage the internal or external funds. Sometimes, in order to access, external sources of funds such as financial institutions, business financial reports are required. Access to finance is critical for the growth of the agriculture sector [3]. Scarcity and inadequacy of funds for agribusiness investment are common in most rural areas of developing countries. As perceived by financial institutions, the limitations of agricultural finance access are due to high delivery cost; proximity; weak farming practices; lack of sufficient collateral; weak collaboration among farmers, etc. [5]. However, some financial institutions have strategized in financing agribusiness enterprises in various schemes.

In Tanzania, National Microfinance Bank (NMB) offers out-grower's loans, a scheme designed to finance eligible farmers dealing with production of crops to get working capital to meet costs of farming, inputs purchase, crop maintenance, harvesting and other related crop development costs. This scheme involves the bank as financier, the buyer and the farmer. The process starts by financing crop inputs to suit specific crop and farmer needs. The harvest is contracted to the buyer who pays the crop proceeds through the bank whereby the loan is repaid and the remainder is available for the farmer group. This scheme enables farmers to borrow enough funds to meet the related farming costs. However, the required collateral to secure the loan is another challenge to the peasants in the rural areas of developing countries. Another financial institution that offers loans to the farmers in Tanzania is CRDB microfinance bank. CRDB bank offers Monetary Financial Institutions (MFI) loans to be disbursed as per schedule of farming activities.

Crops planting and growing are agricultural activities that demand accurate and on time data. The decision-making on what, when, and how to plant and grow crops is supported by the collected data from reliable sources. For example, manpower management, financial plan, start and end of the seasons (rainy and sunny), the area soil condition, suitable types of the crops, list of companies available to provide fertilizers, types of available fertilizers, pesticides, seeds, etc. Processing process involve all activities from harvesting to the distribution and storage processes. It depends on the nature of the market. Packaging may be included in this stage. After harvesting and processing, products are ready for storage or sales. In stock \& inventory business process, the information such as time to deliver, storage capacity, storage conditions are required. Tactics and strategies for distribution, marketing, sales and delivery in agricultural enterprise is the same as other general enterprises. However, the nature of the product may require fast delivery. For example, rice can stay longer than organic (untreated) onions or tomatoes.

\section{Agribusiness System Hub}

In Figure 2, through user interface, a registered farmer is given account in the system. Application server provides 
reports as per the respective business process. Inference engine is the art of the system or the rule interpreter in a rule-based system which uses logical rules to the given knowledge-base to get new information [10]. The knowledge-base, on the other hand, contains facts or rules about the business. Sets of data used by the system are stored in the database. In conventional ERP, employees in all departments can look to the ERP system for the information they need and work from the same data, while in the proposed agriculture system hub, an authorized user will access only data related to his/her product(s) in the integrated database.

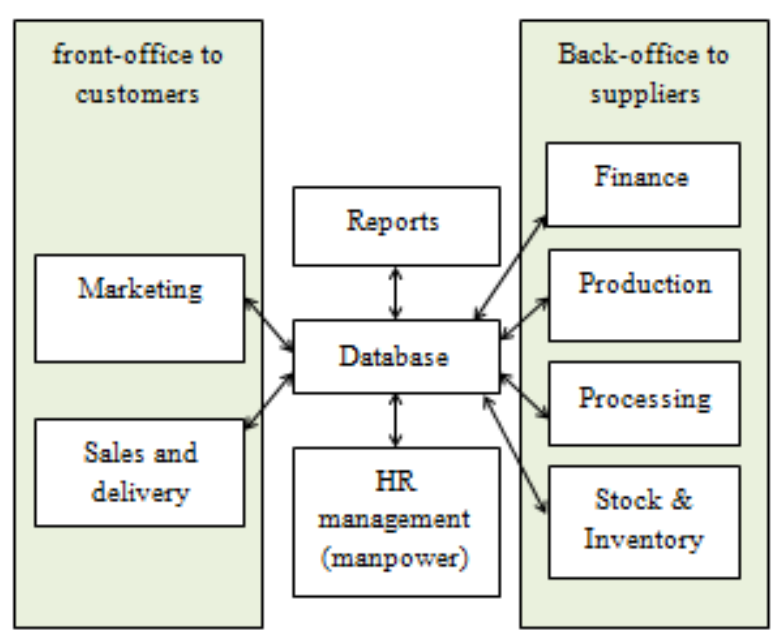

Figure 1. Agribusiness ERP system concept modified from [4]

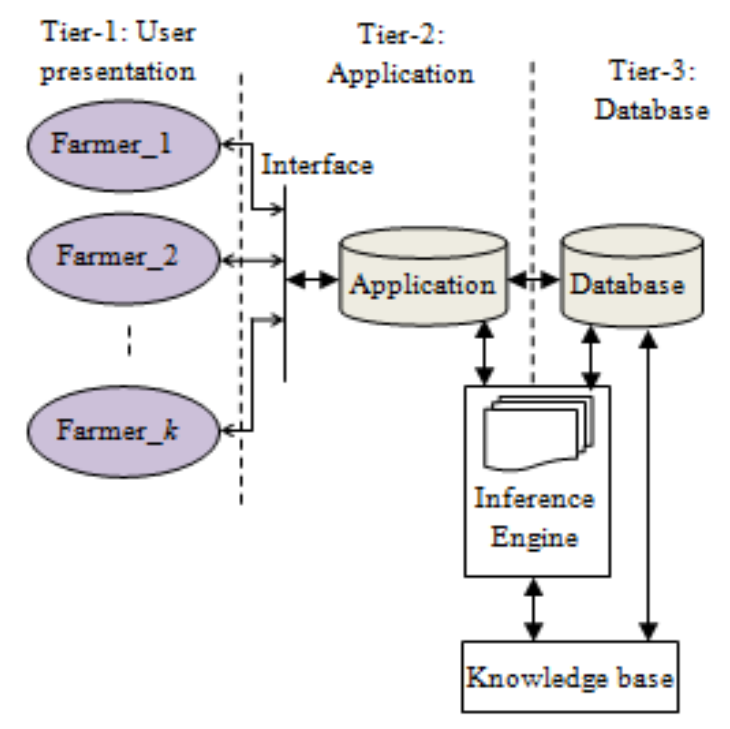

Figure 2. A basic 3-Tier agribusiness system structure [4]

\subsection{Presentation (User Interface) Layer}

The User Interface (UI) or presentation layer is a front layer (control UI) that interacts with the end user. UI is a dialogue structure, that is, a point where farmers, buyers, and suppliers, view related information. The information to be viewed includes fertilizers, suppliers, prices, cash flow, manpower records, weather status and expectations, etc. Developing the UI is a complex task due to the nature of the ERP system and its environments. Capability, supported data format, size, of devices to be used are among the components to be considered. Famers/managers, customers, shareholders, or suppliers, may need to make a decision while on move. This would require UI supported by a mobile device. However, most farmers in the rural areas of developing countries use tele-center's facilities such as personal computers (PCs), to access IT services. Therefore, the design and layout of basic input and output UIs should be simple and easy to use.

\subsection{Application Layer}

The proposed agribusiness system, acts as a middleware platform that integrates farmers into the IT industry. The application layer performs ERP's detailed processing. It enables agribusinesses processes information to be provided to the farmers, suppliers, customers, or stakeholders. Due to dynamic characteristics, that is, the domain information varies with respects to the time conditions. The decision making is based on the new information deduced by the inference engine that applies logical rules to the knowledge base so as to enhance business intelligence.

\subsection{Database Layer}

In ERP system, database is a key feature that serves as a single source of the truth [11,12]. Database layer for agribusiness is responsible for the data storage. The agribusiness data can be classified as sensor data, work information from knowledge base or statistical data, collected data from the field and historical data, data from related agents and organization, deduced data, etc. All these data are classified as master or permanent data collected on entities of the business; transaction data; and configuration data such as types of plants, sales organization, etc. [12]. Being interrelated stored data of different items and players, database for agribusiness must be well designed. Each business process has individual and shared data. The operational database development stages include: data requirements; conceptual data modeling; logical design; distributed design; and physical design [11].

\section{Methodology}

There were surveys and interviews in the rural areas of two regions in Tanzania. Kisaki in Morogoro rural district (Morogoro region) and Mika in Rorya district (Mara region). Agro-economy activities were as shown in Table 1. The data include information about crops as well as livestock in the selected rural areas. 


\subsection{Model Implementation}

Table 1. The livestock keeping and crops production activities

\begin{tabular}{|c|c|c|}
\hline Activity & Location & Response \\
\hline \multirow{4}{*}{$\begin{array}{l}\text { Agro-econo } \\
\text { my } \\
\text { activities }\end{array}$} & \multirow{2}{*}{$\begin{array}{l}\text { Kisaki- } \\
\text { Morogoro } \\
\text { Rural }\end{array}$} & $\begin{array}{c}\text { Farming: } \\
\text { Rice, corns, potatoes, tomatoes, } \\
\text { water-melons, mangoes } \\
\end{array}$ \\
\hline & & $\begin{array}{l}\text { Livestock (pastoralists): } \\
\text { Cow, and goats. }\end{array}$ \\
\hline & \multirow[t]{2}{*}{ Mika -Rorya } & $\begin{array}{c}\text { Farming: } \\
\text { Corn, cassava, sorghum, beans, } \\
\text { sweet potatoes, etc. }\end{array}$ \\
\hline & & $\begin{array}{c}\text { Livestock (mixed): } \\
\text { Cows, sheep and goats. }\end{array}$ \\
\hline \multirow[t]{2}{*}{$\begin{array}{l}\text { Outlet } \\
\text { transport to } \\
\text { market } \\
\text { access }\end{array}$} & $\begin{array}{l}\text { Kisaki } \\
\text { Morogoro } \\
\text { Rural }\end{array}$ & $\begin{array}{l}\text { Train : } 2 \text { times a week to Dar es } \\
\text { Salaam and Zambia } \\
\text { Road: } \\
\text { 1) One to the city of Dar es } \\
\text { Salaam. } \\
\text { 2) Three or four buses to } \\
\text { Morogoro town. }\end{array}$ \\
\hline & Mika- Rorya & $\begin{array}{l}\text { Road: } \\
\text { 1) one to Sirari boarder to Kenya } \\
\text { 2) Hourly buses to Mwanza city } \\
\text { and Musoma town }\end{array}$ \\
\hline \multirow{2}{*}{$\begin{array}{l}\text { Communic } \\
\text { ation }\end{array}$} & $\begin{array}{l}\text { Kisaki } \\
\text { Morogoro } \\
\text { Rural }\end{array}$ & $\begin{array}{l}\text { Mobile phone operators access } \\
\text { available (Tigo, Voda and Airtel) }\end{array}$ \\
\hline & Mika- Rorya & $\begin{array}{l}\text { Mobile phone operators access } \\
\text { available (Tigo, Voda and Airtel) }\end{array}$ \\
\hline \multirow{2}{*}{$\begin{array}{l}\text { Financial } \\
\text { access in } \\
\text { the village }\end{array}$} & $\begin{array}{l}\text { Kisaki } \\
\text { Morogoro } \\
\text { Rural } \\
\end{array}$ & Limited mobile Money \\
\hline & Mika- Rorya & Limited mobile Money access. \\
\hline \multirow[t]{2}{*}{$\begin{array}{l}\text { Output } \\
\text { products } \\
\text { market in } \\
\text { the village }\end{array}$} & $\begin{array}{l}\text { Kisaki } \\
\text { Morogoro } \\
\text { Rural }\end{array}$ & $\begin{array}{c}\text { Farm products: } \\
\text { Small market everyday at } \\
\text { Kisaki center. } \\
\text { Livestock: } \\
\text { Butcheries only, } \\
\text { Other markets: None }\end{array}$ \\
\hline & Mika- Rorya & $\begin{array}{l}\text { Farm products: None. } \\
\text { Livestock: None }\end{array}$ \\
\hline \multirow{2}{*}{$\begin{array}{l}\text { External } \\
\text { Accessible } \\
\text { markets } \\
\text { (Input and } \\
\text { output) }\end{array}$} & $\begin{array}{l}\text { Kisaki } \\
\text { Morogoro } \\
\text { Rural }\end{array}$ & $\begin{array}{l}\text { Dar es Salaam (appr. } 290 \mathrm{~km} \text { by } \\
\text { road or } 5 \text { hours by train) } \\
\text { and Morogoro }\end{array}$ \\
\hline & Mika- Rorya & $\begin{array}{c}\text { Tarime, } \\
\text { Mwanza } \\
\text { Sirari } \\
\text { Musoma } \\
\end{array}$ \\
\hline
\end{tabular}

Agribusiness is characterized by several factors in the communities of rural areas of developing countries, such as low-income (poverty), illiteracy, poor information technologies (IT) infrastructures, resistance-to-change, small-scale agricultural activities, lack of IT expertise, shortage of learning resources centers, etc. The most common food and cash crops in Tanzania are maize, sorghum, cassava, sweet potatoes, cotton, bananas, wheat, and sugar cane [13]. The system design and implementation team members should start by listing the detailed plan of the expected production activities and possible scenarios in order. This should be incorporated in the knowledge base system. All constraints (e.g. funds, land, rainfalls, manpower, etc.) and guiding rules are used to plan the production processes. Farmers will be able to intercede to optimize these planning scenarios. If well planned, the proposed agribusiness system hub tool will be used to manage the available fund, production, processing, stock \& inventory, marketing, sales, distribution, and delivery business processes. Suppliers, customers, and famers operations are integrated therein. Therefore, ERP-H integrates agribusiness operations in the community into a single entity. Farmers in a community create crops accounts to access the ERP and customize the account according to the input/output services and products.

\subsubsection{Database}

The discussion starts by the design of the system database focusing on the conceptual design. The entity-relationship (ER) diagram template of the proposed agribusiness is presented in Figure 3. Entities (with identifier attribute only) and relationships elements are depicted. The ER diagrams showing famer and crop entities and attributes relationship are shown in Figure 4. The suppliers information such as locations, items (e.g. fertilizer, pesticide, seeds, etc), prices, time-to-deliver, stock status, are made available and accessible to the farmers.

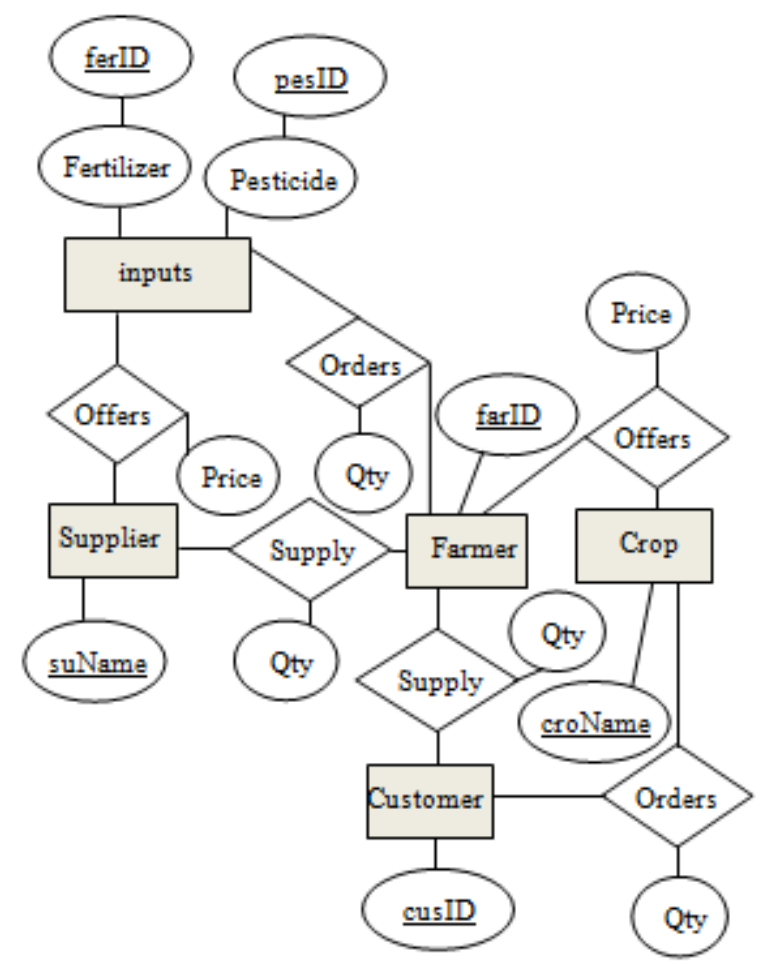

Figure 3. The ER diagram template of proposed agribusiness database

Input supplier in this case supplies fertilizers and pesticides. The supplies entity-relationship diagram and attributes are depicted in Figure 5. Farmer can purchase inputs from suppliers and all related documents in the 
supply chain will be generated. Similarly, customers can order the products direct from the farmers and the order is directed to the selected agribusiness system account. In actual fact, each farmer has access to all respective customized modules and reports to support decision-making process. Available stock levels and time to deliver are provided to the buyers and managers. In order to extend the market places, agribusiness system hub will facilitate the sales process online. Using online based payment, third-party application is integrated with agribusiness system hub. The customer and order entities relationship diagram is shown in Figure 6. Finally, the inventory ER diagram is presented in Figure 7.

The opportunity and competitiveness are extended globally regardless of the farmer's physical address. Our discussion is about how to create the product model, category model, sales model, cart model, and their respective database. Sample list of items used to set up database are: product (crop name), crop category, crop ID, price, description, Quantity in stock, etc. Product model contain all the data about products, such as crops. When products are grouped in various categories, the categories model is formed. In the marketing business processes, customers need access to the products on web application in order to purchase. Cart model gives customers access to browse selected items (products) in the shopping cart.

Farmer, suppliers and customers interact through online application, and the product is the key element for the enterprise success. Responses and whispers received are analyzed, and incorporated as new updates in knowledge based. In fact, products on sale, locations, delivery day/time, and any other updates are reported accordingly to business partners. Based on the nature of the agricultural business (crops in particular), if the products will be delivered, inference engine will learn the order and its related constraints, such as customer location, weather, means of transportation (available infrastructure) and crop condition, to check if the delivery will be possible on time and in good condition. If the conditions are not going to be met, the new proposal from other famers will be proposed to the customer accompanied by the related information. The customer may accept or decline the proposal.

\subsubsection{Application Server}

The application server resides in the middle-tier of the agribusiness system dedicated in a specific business applications and related transactions. Tailor-made agribusiness system developed to meet the business needs allow you to own the system and its full source content. This gives freedom to add more features when needed. The knowledge based system can be encapsulated into the system so as to give more intelligence in decision making for a business involving dynamic activities like agribusiness. Updated data from the domain are utilized in deriving new information to be used in decision making and predictions. For example, season information can be utilized during planning the kind of crop to cultivate. Other dynamic information making such as road status, market place and price, orders, and other outside elements, are used in analysis towards the optimization and decision making.

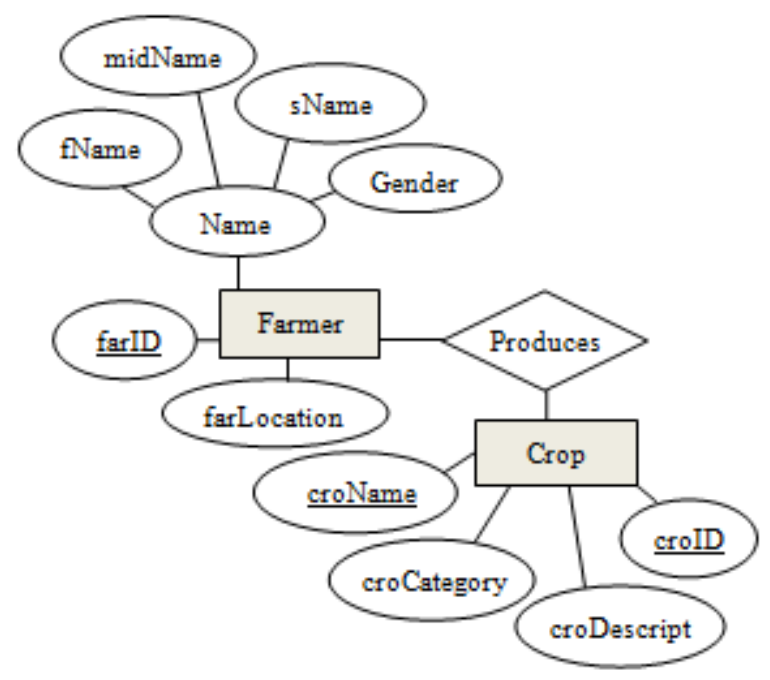

Figure 4. Farmer and Crop ER schema diagram

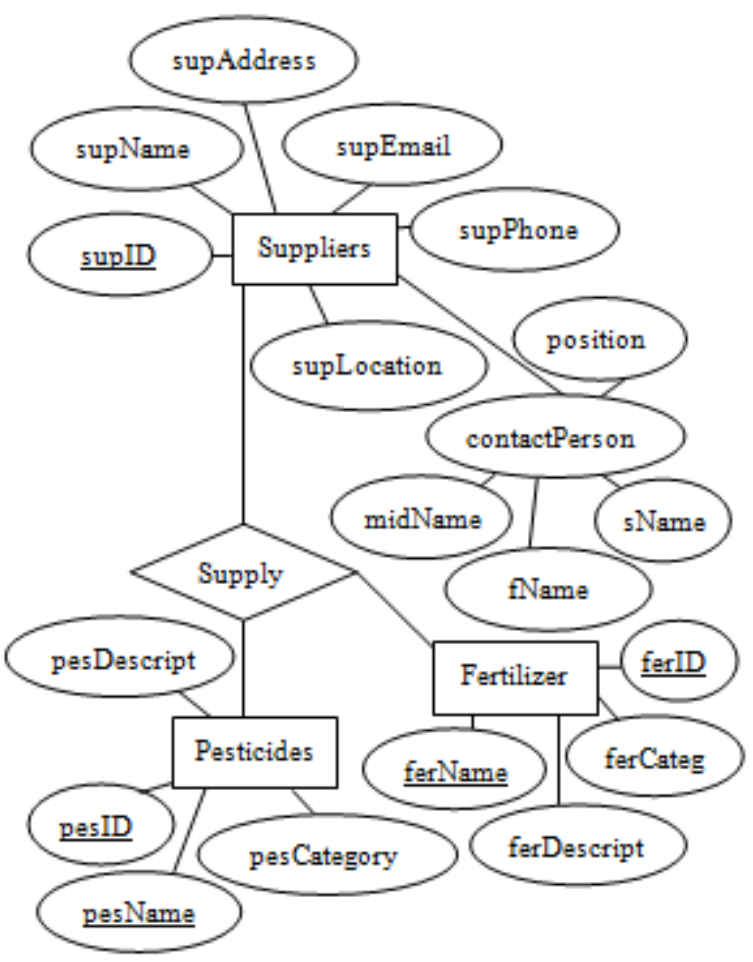

Figure 5. Supplier ER diagram

\section{Conclusions}

The ERP system would be used to improve farm operational efficiency and increases the productivity and enhance customer satisfaction. However, due to the nature of the conventional ERP and its cost, individual peasants 
cannot afford it. Therefore, this paper presents a tailor-made agribusiness system hub designed from scratch to meet the agribusiness in the rural area. The proposed agribusiness system hub gives freedom on the software implementation. It is advised that servers should be in a well structured locations. This is because, when lots of traffic starts the performance if affected which can jeopardize the business operations. Moreover, in the rural areas of most developing countries, the technical support equipped telecentres facilitate most of IT applications.

\section{Acknowledgements}

The author would like to extend appreciations to Dar es Salaam Institute of Technology (DIT) for supporting this work.

\section{REFERENCES}

[1] J. Rock Do, J. H. Kim, Y. C. Choe, "Success factors for the implementation of ERP to the Agricultural Products Processing Center," Advanced Science and Technology Letters, Vol. 95, pp.61-66, 2015.

[2] S.S. Bhavikatti, A Textbook of Agronomy, New Age Publishers, New Delhi, 2010.

[3] M. Ruete, "Financing for Agriculture: How to boost opportunities in developing countries," International Institute for Sustainable Development (IISD), Investment in Agriculture, Policy Brief No. 3, 2015.

[4] J. A. Hall, Accounting Information Systems, Seventh Edition, Cengage Learning, 2011.

[5] A. Gashayie, M. Singh, "Agricultural Finance Constraints and Innovative Models Experience for Ethiopia: Empirical Evidence from Developing Countries," Research Journal of Finance and Accounting, Vol.6, Issue 7, pp. 39-49, 2015.

[6] B.Y, Chung, M.J. Skibniewski, Y. H. Kwak. "Developing ERP Systems Success Model for the Construction Industry," Journal of Construction Engineering and Management, Vol. 135, Issue 3, pp. 207-216, 2009.

[7] G. Gable, D. Sedera, T. Chan, "Enterprise systems success: A measurement model," Proceedings of the International Conference of Information Systems (ICIS), Seattle, USA, 2003, pp. 576-591.

[8] S. Venkatraman, K. Fahd, "Challenges and Success Factors of ERP Systems in Australian SMEs," Systems, Vol. 4, 2016.

[9] J.W. Kruize, J. Wolfert, H. Scholten, C.N. Verdouw, A. Kassahun, A.J.M. Beulens. "A reference architecture for Farm Software Ecosystems," Computers and Electronics in Agriculture Journal, Vol. 125, pp 12-28, 2016.

[10] E. Turban, Decision Support and Expert Systems: Management support system. Fourth Edition. Prentice Hall, 1995.
[11] R. Elmasri and S. B. Navathe. Fundamentals of database systems. Sixth edition, Pearson Education, Inc. 2011.

[12] M. Bradford. Modern ERP: Select, Implement, \& Use Today's Advanced Business Systems. Third Edition, North Carolina State University, 2015.

[13] D. Fischer. "Assessment of the agricultural sector in Tanzania," USAID Tanzania Economic growth office, 2003.

[14] Y. Lee, J. Do, Y. Choe. "Study on Factors for Improving the Effectiveness of ERP within Korea Agricultural Products Processing Center," Journal of Research in Business and Management, Vol.5, Issue 2, pp. 89-92, 2017.

[15] A. F. McCalla. "Challenges to World Agriculture in the 21st Century," Agricultural and Resource Economics, University of California, Davis, Vol. 4 Issue 3, 2001.

[16] S. Maghimbi. "Cooperatives in Tanzania Mainland: Revival and Growth," International Labour Organization, Cooperative Facility for Africa, 2010. 